\title{
C-F Bond Activation by Transient Phosphenium Dications
}

\author{
Nemanja Đorđević†, Madelyn Qin Yi Tay ${ }^{\dagger}$, Senthilkumar Muthaiah, Rakesh Ganguly ${ }^{\dagger}$, Dušan Dimić \\ Dragoslav Vidović ${ }^{\dagger *}$
}

†SPMS-CBC, Nanyang Technological University, 21 Nanyang Link, Singapore, 638737.

"National Institute of Technology Kurukshetra, Kurukshetra-136119, Haryana, India.

‡ Faculty of Physical Chemistry, University of Belgrade, n10oo Belgrade, Republic of Serbia.

Supporting Information Placeholder

\begin{abstract}
C}-\mathrm{F}$ bond cleavage by transient $\mathrm{P}(\mathrm{III})$-based dications $\left[\mathrm{RP}\left(\mathrm{C}\left(\mathrm{PPh}_{3}\right)_{2}\right)\right]^{2+}\left(\mathbf{4 a}^{\mathbf{2}}: \mathrm{R}=\mathrm{Ph} ; \mathbf{4 b}^{\mathbf{2}}: \mathrm{R}=4-\mathrm{F}-\mathrm{Ph}\right)$ is reported. These dications were generated by the reaction of the corresponding monocationic precursors with excess $\mathrm{Na}\left[\mathrm{BAr}_{4}{ }^{\mathrm{Cl}}\right]$. Evidence for the existence of the transient dicationic species was obtained by trapping the dication $\mathbf{4 a}^{\mathbf{2}+}$ with $\mathrm{PMe}_{3}$. According to theoretical analysis the low laying LUMOs of these species were responsible for the observed activation of C-F bonds.
\end{abstract}

Organic compounds containing carbon-fluoride (C-F) bonds continue to attract the scientific community due to their importance in both industrial and academic research. C-F bonds are not only among the strongest single bonds, in general, but are also the strongest single bond that carbon forms with any other element. ${ }^{1}$ Considering that these particular bonds show exceptional kinetic inertness it is not surprising that various organofluorine compounds are extremely useful as durable goods such as PTFE and high performance lubricants. However, the inherent thermodynamic and kinetic C-F bond stability renders these perfluorinated compounds environmentally persistent and difficult to degrade and/or recycle. ${ }^{2}$ For example, the atmospheric half-life for $\mathrm{CF}_{4}$ is greater than $5.0 \times 10^{4}$ years so the disposal of organofluorine waste remains a challenge. ${ }^{3}$ Significant efforts have been made to develop various methods for the $\mathrm{C}-\mathrm{F}$ bond activation. Metal mediated $\mathrm{C}-\mathrm{F}$ bond cleavage reactions ${ }^{4}$ are predominant in this field but more attractive non-metal systems are also emerging. Siliconbased compounds (e.g. $\mathrm{Et}_{3} \mathrm{Si}^{+}$) dominate the non-metal field presumably due to the silicon's high affinity for fluorine; the Si-F bond dissociation energy is $\sim 140 \mathrm{kcal} / \mathrm{mol} .{ }^{5}$ In fact, most systems capable of catalytic C-F activation use silanes as fluorine scavengers. ${ }^{6}$ Lewis acidic boron- and aluminum-based compounds were also reported to be effective in $\mathrm{C}-\mathrm{F}$ bond functionalizations. ${ }^{5 \mathrm{~m}, 7,8}$ Recently, Stephan and co-workers have shown that organofluorophosphonium cations (i.e. $\mathrm{P}(\mathrm{V})$-based cations) could be used in catalytic $\mathrm{C}-\mathrm{F}$ activation corresponding to the very first examples of this type of activation performed at a phosphorus centre. ${ }^{9}$ However, to the best of our knowledge, there are no examples of $\mathrm{P}(\mathrm{III})$-based species being involved in a $\mathrm{C}-\mathrm{F}$ bond activation. Therefore, we wish to report a transient $\mathrm{P}(\mathrm{III})$-based dications capable of activating $\mathrm{C}-\mathrm{F}$ bonds of the $\left[\mathrm{BAr}_{4}^{\mathrm{f}}\right]^{-}$anion $\left(\mathrm{Ar}^{\mathrm{f}}=\right.$ $\left.\left(\mathrm{CF}_{3}\right)_{2}-\mathrm{C}_{6} \mathrm{H}_{3}\right)$ and $\alpha, \alpha, \alpha$-trifluorotoluene $\left(\mathrm{PhCF}_{3}\right)$.

Recently, our group has reported the first example of a coordinatively unsaturated $\mathrm{P}(\mathrm{III})$ dication, $\left[{ }^{\mathrm{P}} \mathrm{Pr}_{2} \mathrm{NP}\left(\mathrm{C}\left(\mathrm{PPh}_{3}\right)_{2}\right)\right]^{2+}$, and its reactivity towards water and methanol. ${ }^{10}$ Our next target was to potentially enhance the Lewis acidic properties of the
Scheme 1. General synthetic procedures.

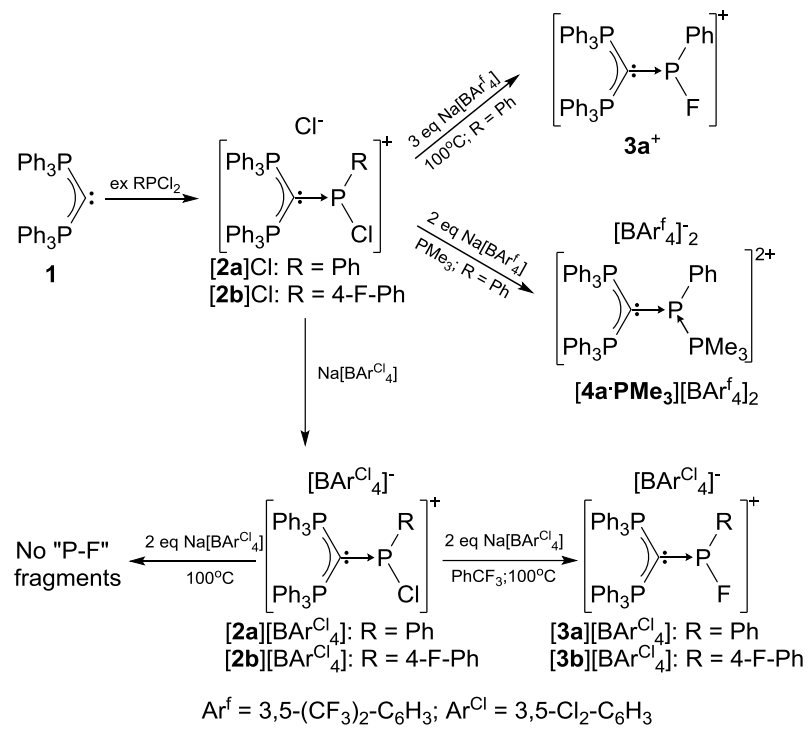

dication by replacing the amino substituent with phenyl $(\mathrm{Ph})$ and 4-fluorophenyl (4-F-Ph) groups. Using the procedure described for the synthesis of the amino-substituted dication, the corresponding monocationic precursors $\left[\mathrm{RPCl}\left(\mathrm{C}\left(\mathrm{PPh}_{3}\right)_{2}\right)\right] \mathrm{Cl}([\mathbf{2 a}] \mathrm{Cl}$ : $\mathrm{R}$ $=\mathrm{Ph} ;[\mathbf{2} \mathrm{b}] \mathrm{Cl}: \mathrm{R}=4-\mathrm{F}-\mathrm{Ph})$ were synthesized by the addition of free carbone ${ }^{11} \mathrm{C}\left(\mathrm{PPh}_{3}\right)_{2}, \mathbf{1}$, to a benzene solution containing excess of $\mathrm{RPCl}_{2}(\mathrm{R}=\mathrm{Ph}, 4-\mathrm{F}-\mathrm{Ph})$ as described in Scheme 1. The carbone-for-chloride replacement was manifested by the presence of a triplet $(\sim 111 \mathrm{ppm})$ and a doublet $(\sim 26 \mathrm{ppm})$ in the ${ }^{31} \mathrm{P}$ NMR spectra corresponding to the central and carbone's phosphorus atoms, respectively. The structural identity of these two monocationic precursors was elucidated by single crystal X-ray diffraction (Figure 1) when the chloride anion was replaced by $\mathrm{SbF}_{6}$. However, [2a] $\left[\mathrm{SbF}_{6}\right]$ exhibited a high degree of disorder resulting in ambiguous structural parameters which are excluded from further discussion. The values for the bond angles around the central $\mathrm{P}$ atom for $\mathbf{2 b}^{+}\left(312.01(7)^{\circ}\right)$ confirmed the expected pyramidal geometry for these species. Both the P3-C1 (1.7828(13) $\AA$ ) and P3-Cl1 (2.1271(5) A) bond distances for $\mathbf{2 b}^{+}$were somewhat shorter than the analogous bond distances for $\left[{ }^{\mathrm{P}} \mathrm{Pr}_{2} \mathrm{NPCl}\left(\mathrm{C}\left(\mathrm{PPh}_{3}\right)_{2}\right)\right]^{+}(1.812(5)$ and $2.173(2) \AA$, respectively $) .{ }^{10 \mathrm{a}}$ This was expected considering greater $\pi$-electron donation ability of the amino substituent with respect to 4-F-Ph and $\mathrm{Ph}$. However, a shorter $\mathrm{P}-\mathrm{Cl}$ bond for $\mathbf{2 b}^{+}$(and presumably for $\mathbf{2 a}^{+}$) suggested 
that the chloride abstraction from $2 \mathbf{a}^{+} / \mathbf{2} \mathbf{b}^{+}$and the subsequent formation of the target dications could be more challenging than in the case of the amino analogue.

Indeed, the $\mathrm{P}-\mathrm{Cl}$ bond was not cleaved after addition of 2 or 3 equiv of $\mathrm{Na}\left[\mathrm{BAr}_{4}{ }_{4}\right]$ to a solution containing either [2a]Cl or $[\mathbf{2 b}] \mathrm{Cl}$ at room temperature. However, leaving the reaction mixture of [2a]Cl and 3 equiv of $\mathrm{Na}\left[\mathrm{BAr}^{\mathrm{f}} 4\right]$ in 1,2-difluorobenzene at $100^{\circ} \mathrm{C}$ overnight in an J. Young NMR tube resulted in disappearance of the triplet signals at $\delta_{\mathrm{P}}$ assigned to $[\mathbf{2 a}]^{+}$, and appearance of a new doublet of triplets at $\delta \mathrm{P} 162.2 \mathrm{ppm}$. The signal was assigned to the central phosphorus with the carbone substituent causing the triplet splitting while the value for the doublet coupling constant of $976 \mathrm{~Hz}$ suggested the formation of a P-F fragment. The presence of this fragment was confirmed by observing analogous signal in the ${ }^{19} \mathrm{~F}$ NMR spectrum at $-161.2 \mathrm{ppm}$ having the same value for the coupling constant. The crude product, containing other unidentified products according to ${ }^{31} \mathrm{P}$ and ${ }^{19} \mathrm{~F}$ NMR spectroscopy, was also subjected to ES-MS resulting in the identification of a signal at $\mathrm{m} / \mathrm{z} 663.2006$ (calc for $\mathrm{C}_{43} \mathrm{H}_{35} \mathrm{FP}_{3}: \mathrm{m} / \mathrm{z}$ 663.1936) whose isotope pattern was in excellent agreement with fluorinated monocation $\left[\mathrm{PhPF}\left(\mathrm{C}\left(\mathrm{PPh}_{3}\right)_{2}\right)\right]^{+}, \mathbf{3 a}^{+}$. Unfortunately, unsuccessful attempts have been made to structurally elucidate this compound. However, additional evidence for the identity of $\mathbf{3 a}^{+}$was gained by reacting [2a] $\left[\mathrm{BAr}^{\mathrm{Cl}}\right]\left(\mathrm{Ar}{ }^{\mathrm{Cl}}=3,5-\mathrm{Cl}_{2}-\mathrm{C}_{6} \mathrm{H}_{3}\right.$, see below) with excess KF resulting in identical ${ }^{19} \mathrm{~F}$ and ${ }^{31} \mathrm{P}$ NMR spectroscopic data.

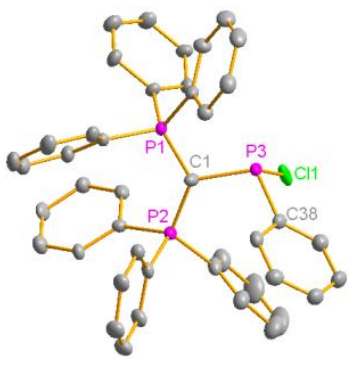

$[2 \mathrm{a}]\left[\mathrm{SbF}_{6}\right]$

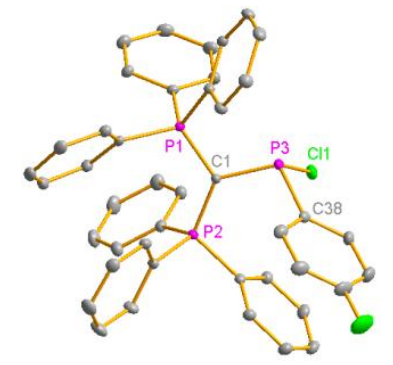

[2b] $\left[\mathrm{SbF}_{6}\right]$

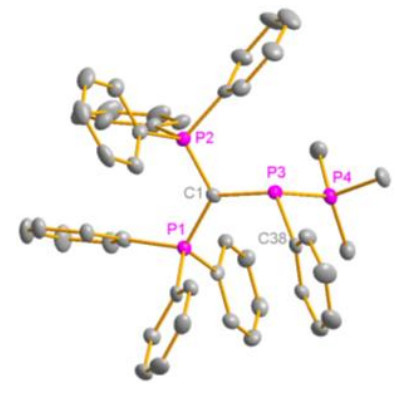

$\left[4 \mathrm{a} \cdot \mathrm{PMe}_{3}\right]\left[\mathrm{BAr}_{4}^{\mathrm{f}}\right]_{2}$

Figure 1. Single crystal X-ray structures for $[\mathbf{2 a}]\left[\mathrm{SbF}_{6}\right],[\mathbf{2 b}]\left[\mathrm{SbF}_{6}\right]$ and $\left[\mathbf{4 a} \cdot \mathbf{P M e}_{3}\right]\left[\mathrm{BAr}_{4}^{\mathrm{f}}\right]_{2}$ at $50 \%$ probability. The counterions, hydrogen atoms as well as the observed disorder for $\mathbf{2 a}^{+}$were omitted for clarity.

Even though the source of the fluoride (the anion or solvent) was not immediately evident it was suspected that the transient and highly reactive nature of dication $\left[\mathrm{PhP}\left(\mathrm{C}\left(\mathrm{PPh}_{3}\right)_{2}\right)\right]^{2+}$, $[4 \mathbf{a}]^{2+}$, was responsible for the observed fluoride abstraction. The most appealing evidence for the existence of this dication was gained by a trapping experiment involving the addition of $\mathrm{PMe}_{3}$ in a solution containing [2a]Cl and 2 equiv of $\mathrm{Na}$ [BAr ${ }_{4}^{\mathrm{f}}$ ] (Scheme 1). The ${ }^{31} \mathrm{P}$ NMR spectrum of this reaction mixture contained three second order signals at $\delta_{\mathrm{p}}-6.4$ (doublet of triplets), 11.4 (doublet of triplets) and 28.7 (doublet) ppm while the ES-MS spectrum revealed the presence of a peak at m/z 360.1197 (calcd. for $\left[\mathrm{C}_{46} \mathrm{H}_{44} \mathrm{P}_{4}\right]^{2+}: \mathrm{m} / \mathrm{z}$ 360.1191). These results were consistent with the formation of adduct $\left[\mathrm{PhP}\left(\mathrm{PMe}_{3}\right)\left(\mathrm{C}\left(\mathrm{PPh}_{3}\right)_{2}\right)\right]\left[\mathrm{BAr}_{4}^{\mathrm{f}}\right]_{2}$, $\left[4 \mathbf{a} \cdot \mathrm{PMe}_{3}\right]\left[\mathrm{BAr}_{4}^{\mathrm{f}}\right]_{2}$. Indeed, single crystal $\mathrm{X}$-ray analysis of this product confirmed its identity as the $\mathrm{PMe}_{3}$-trapped adduct of $\mathbf{4} \mathbf{a}^{\mathbf{2 +}}$ dication (Figure 1). The P3-C1 (1.792(4) Å) and P3-C38 (1.826(4) $\AA$ ) bond distances are essentially equivalent with respect to $\mathbf{2 b}^{+}$ while the P3-P4 (2.217(2) Å) bond distance is quite comparable with the analogous distance observed for $\left[\mathrm{Ph}_{2} \mathrm{P}-\mathrm{PMe}_{3}\right]^{+}(2.187(2)$ A). ${ }^{12}$

In order to gather more information on the source of the fluoride ion $\mathrm{Na}\left[\mathrm{BAr}_{4}^{\mathrm{f}}\right]$ was replaced with $\mathrm{Na}\left[\mathrm{BAr}^{\mathrm{Cl}} 4\right]\left(\mathrm{Ar}^{\mathrm{Cl}}=3,5-\mathrm{Cl}_{2}-\right.$ $\mathrm{C}_{6} \mathrm{H}_{3}$ ). In fact, the non-coordinating chloride ions of the monocationic precursors $[\mathbf{2 a}] \mathrm{Cl}$ and $[\mathbf{2 b}] \mathrm{Cl}$ were first replaced by $\left[\mathrm{BAr}^{\mathrm{Cl}}\right]^{-}$to obtain $[\mathbf{2 a}]\left[\mathrm{BAr}_{4}{ }^{\mathrm{Cl}}\right]$ and $[\mathbf{2 b}]\left[\mathrm{BAr}^{\mathrm{Cl}} 4\right]$, respectively (Scheme 1). Then, to a 1,2-difluorobenzene solution containing either of these two monocations 2 equiv of $\mathrm{Na}\left[\mathrm{BAr}^{\mathrm{Cl}}{ }_{4}\right]$ was added and the mixture was heated to $100^{\circ} \mathrm{C}$ and kept overnight. In both instances there was no evidence for any 'P-F' fragment formation eliminating the solvent as the fluoride source in the original reaction. Then, to the same reaction mixtures 1 equiv of $\mathrm{PhCF}_{3}$ was added and after heating for several hours, the formation of $\mathbf{3 a}^{+}$ and $\left[4-\mathrm{F}-\mathrm{PhPF}\left(\mathrm{C}\left(\mathrm{PPh}_{3}\right)_{2}\right)\right]^{+}, \mathbf{3 b}^{+}$, were detected. These observations clearly indicated that the source of the fluoride in the initial experiment(s) was the $\left[\mathrm{BAr}_{4}^{\mathrm{f}}\right]^{-}$anion. ${ }^{13}$

Furthermore, heating a 1:1 molar mixture of $\mathrm{Na}\left[\mathrm{BAr}_{4}\right]$ and $\mathrm{PhCF}_{3}$ showed no reactivity, based on ${ }^{19} \mathrm{~F}$ NMR spectroscopy, providing more evidence that the transient dications were responsible for the $\mathrm{C}-\mathrm{F}$ cleavage of the fluorinated compounds $\left(\mathrm{PhCF}_{3}\right.$ and $\mathrm{BAr}_{4}^{-}$). Unfortunately, other fluorinated substrates such as $\left(\mathrm{CF}_{3} \mathrm{CH}_{2}\right)_{2} \mathrm{O}, \mathrm{C}_{6} \mathrm{~F}_{5} \mathrm{Br}$ and $\mathrm{CF}_{3}\left(\mathrm{CF}_{2}\right)_{6} \mathrm{CHF}_{2}$ were not activated by the transient dications because there was no evidence for the formation of a P-F fragment after introducing these substrates in the reaction mixture containing a monocationic precursor $\left([\mathbf{2 a}]\left[\mathrm{BAr}_{4} \mathrm{Cl}_{4}\right]\right.$ or $\left.[\mathbf{2 b}]\left[\mathrm{BAr}_{4}\right]\right)$ and 2 equiv $\mathrm{Na}\left[\mathrm{BAr}_{4} \mathrm{Cl}_{4}\right]$. This is presumably due to the absence of a $\mathrm{Ph}$ group adjacent to the targeted $\mathrm{C}-\mathrm{F}$ bond cleavage in these substrates with respect to $\mathrm{PhCF}_{3}$ and $\mathrm{BAr}_{4}{ }_{4}^{-}$as the presence of $\mathrm{Ph}$ ring(s) was reported to assist in the stabilization of the corresponding carbocations. ${ }^{14}$ Nevertheless, to the best of our knowledge the transient dications formed in this work are the first examples of compounds containing a P(III)centre capable of cleaving C-F bonds.

With the aim to better understand the difference in reactivity and stability between $\mathbf{4 a}^{\mathbf{2 +}}$ and $\mathbf{4} \mathbf{b}^{\mathbf{2 +}}\left(\left[4-\mathrm{F}-\mathrm{PhP}\left(\mathrm{C}\left(\mathrm{PPh}_{3}\right)_{2}\right)\right]^{2+}\right)$ on one side and $\left[{ }^{[} \mathrm{Pr}_{2} \mathrm{NP}\left(\mathrm{C}\left(\mathrm{PPh}_{3}\right)_{2}\right)\right]^{2+}$ on the other, these dications were subjected to theoretical investigations using the Gaussian 09 package. The dicationic structures were fully optimized by the B3PW91 method using the $6-31 \mathrm{G}(\mathrm{d})$ basis set. As the nature of the frontier orbitals for these three dications was virtually identical only the orbitals for $\mathbf{4 a}^{+}$are shown in Figure 2. ${ }^{8 a}$ The LUMOs correspond to the $\pi^{*}$ for the allene-like CPX fragment $\left(\mathbf{4 a}^{\mathbf{2 +}} / \mathbf{4} \mathbf{b}^{\mathbf{2 +}}\right.$ : $\left.\mathrm{X}=\mathrm{C} ;\left[{ }^{[} \mathrm{Pr}_{2} \mathrm{NP}\left(\mathrm{C}\left(\mathrm{PPh}_{3}\right)_{2}\right)\right]^{2+}: \mathrm{X}=\mathrm{N}\right)$ while the HOMOs seem to be mainly non-bonding for the same fragment with a possible mixing from the lone pair orbital on the central $\mathrm{P}$ forming helicallike orbitals. ${ }^{15}$ The energy levels of the HOMOs for all three dications were also similar $(-0.43791,-0.43854$ and $-0.43453 \mathrm{eV}$ for $\mathbf{4 a}^{\mathbf{2 +}}, \mathbf{4} \mathbf{b}^{\mathbf{2 +}}$ and $\left[\mathrm{Pr}_{2} \mathrm{NP}\left(\mathrm{C}\left(\mathrm{PPh}_{3}\right)_{2}\right)\right]^{2+}$, respectively). However, the LUMOs for $\mathbf{4 a}^{2+}(-0.31248 \mathrm{eV})$ and $\mathbf{4} \mathbf{b}^{\mathbf{2 +}}(-0.31315 \mathrm{eV})$ were found to be much more accessible with respect to $\left[{ }^{i} \operatorname{Pr}_{2} \mathrm{NP}\left(\mathrm{C}\left(\mathrm{PPh}_{3}\right)_{2}\right)\right]^{2+}(-0.28129 \mathrm{eV})$. Similar observations were reported when the amino substituents for bis(amino)phosphenium cations were replaced with $\mathrm{Ph}$ groups. ${ }^{16}$ Thus, the reactivity $(\mathrm{C}-\mathrm{F}$ activation) and the transient nature of these $\mathrm{Ph}$-substituted phosphenium dications could be attributed to the low laying LUMOs. Interestingly, according to the natural bond order (NBO) analysis the partial charges of the central $\mathrm{P}$ for $\mathbf{4 a}^{2+}(+1.02 e)$ and $4 \mathbf{b}^{2+}(+1.02 e)$ were found to be less positive in comparison to 
$\left[{ }^{\mathrm{i}} \mathrm{Pr}_{2} \mathrm{NP}\left(\mathrm{C}\left(\mathrm{PPh}_{3}\right)_{2}\right)\right]^{2+} \quad(+1.22 e)$. This might be due to electron density overcompensation from the carbone substituent to the central $\mathrm{P}$ in $\mathbf{4 a}^{\mathbf{2 +}} \mathbf{4} \mathbf{b}^{\mathbf{2 +}}$ in comparison to $\left.{ }^{i} \mathrm{Pr}_{2} \mathrm{NP}\left(\mathrm{C}\left(\mathrm{PPh}_{3}\right)_{2}\right)\right]^{2+}$. Nevertheless, this suggested that Lewis acid-type behavior of a compound might not necessarily be governed by its electron depletion at the central element as much as by the availability of its LUMO.

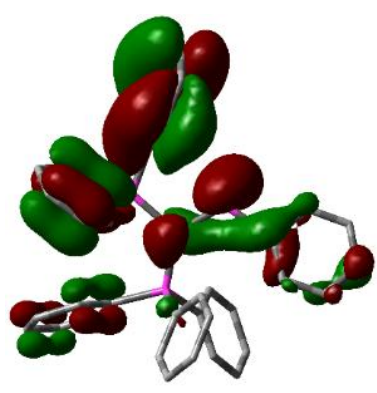

HOMO

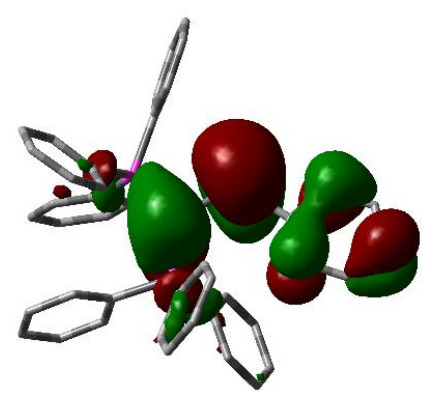

LUMO
Figure 2. The frontier orbitals for $4 \mathbf{a}^{2+}$.

In summary, we have demonstrated that a couple of transient phosphenium dications $\left[\mathrm{RP}\left(\mathrm{C}\left(\mathrm{PPh}_{3}\right)_{2}\right]^{2+}(\mathrm{R}=\mathrm{Ph}, 4-\mathrm{F}-\mathrm{Ph})\right.$ were capable of activating $\alpha$-phenyl $\mathrm{C}$-F bonds. According to the theoretical analysis the greater accessibility of the LUMOs for these transient species in comparison to $\left[{ }^{[} \operatorname{Pr}_{2} \mathrm{NP}\left(\mathrm{C}\left(\mathrm{PPh}_{3}\right)_{2}\right]^{2+}\right.$ was the main reason for the observed reactivity. We are currently exploring the possibility of designing a catalytic cycle for C-F bond activation and all results will be reported in due course.

\section{ASSOCIATED CONTENT}

\section{Supporting Information}

Details for the general experimental procedures, crystallographic techniques and theoretical analysis. "This material is available free of charge via the Internet at http://pubs.acs.org."

\section{AUTHOR INFORMATION}

\section{Corresponding Author}

*Email: dvidovic@ntu.edu.sg

\section{Funding Sources}

A*STAR (grant \# 1220703062).

\section{Notes}

The authors declare no competing financial interests.

\section{ACKNOWLEDGMENT}

We would like to thank Professor Milena Petković from Faculty of Physical Chemistry, University of Belgrade, Serbia, for insightful discussion regarding the theoretical analysis.

\section{REFERENCES}

(1) (a) Smart, B. E. Mol. Struct. Energ. 1986, 3, 141-191. (b) Hudlicky, M. Chemistry of Organic Fluorine Compounds; Prentice- Hall: New York, 1992; p 175. (c) Hiyama, T. Organofluorine Compounds Chemistry and Applications; Springer: New York, 2000. (d) Uneyama, K. Organofluorine Chemistry; Blackwell: Oxford, U.K., 2006. (e) O'Hagan, D. Chem. Soc. Rev. 2008, 37, 308.

(2) Organofluorine chemistry, Principles and Commercial Applications

(Eds. : R. E. Banks, B. E. Smart and J. C. Tatlow), Plenum, NY, 1994.

(3) Ravishankara, A. R.; Solomon, S.; Turnipseed, A. A.; Warren, R. F. Science 1993, 259, 194.
(4) See for example: (a) Kiplinger, J. L.; Richmond, T. G.; Osterberg, C. E. Chem. Rev. 1994, 94, 373. (b) Richmond, T. G. In Topics in Organometallic Chemistry; Murai, S., Ed.; Springer: New York, 1999; Vol. 3, p 243. (c) Reinhold, M.; McGrady, J. E.; Perutz, R. N. J. Am. Chem. Soc. 2004, 126, 5268, and references within. (d) Torrens, H. Coord. Chem. Rev. 2005, 249, 1957. (e) Perutz, R. N.; Braun T. In Comprehensive Organometallic Chemistry III; Crabtree, R. H., Mingos, M. P., Eds.; Elsevier: Oxford, 2007; Vol. 1, pp 725. (f) Clot, E.; Eisenstein, O.; Jasim, N.; Macgregor, S. A.; McGrady, J. E.; Perutz, R. N. Acc. Chem. Res. 2011, 44, 333. (g) Amii, H.; Uneyama, K. Chem. Rev. 2009, 109, 2119. (h) Ahrens, T.; Kohlmann, J.; Ahrens, M.; Braun, T. Chem. Rev. 2015, 115, 931. And references within.

(5) (a) Reed, C. A. Acc. Chem. Res. 1998, 31, 325. (b) Azhakar, R.; Roesky, H. W.; Wolf, H.; Stalke, D. Chem. Commun. 2013, 49, 1841. (c) Stahl, T.; Klare, H. F. T.; Oestreich, M. J. Am. Chem. Soc. 2013, 135, 1248. (d) Stahl, T.; Klare, H. F. T.; Oestreich, M. ACS Catal. 2013, 3, 1578. And references within.

(6) See for example: : (a) Yang, J.; Brookhart, M. J. Am. Chem. Soc. 2007, 129, 12656. (b) Reade, S. P.; Mahon, M. F.; Whittlesey, M. K. J Am. Chem. Soc. 2009, 131, 1847. (c) Kuehnel, M. F.; Holstein, P.; Kliche, M.; Krüger, J.; Matthies, S.; Nitsch, D.; Schutt, J.; Sparenberg, M.; Lentz, D. Chem. Eur. J. 2012, 18, 10701 .

(7) (a) Hirano, K.; Fujita, K.; Yorimitsu, H.; Shinokubo, H.; Oshima, K. Tetrahedron Lett. 2004, 45, 2555. (b) Caputo, C. B.; Stephan, D.W. Organometallics 2012, 31, 27.

(8) (a) Vol'plin, M. E.; Shevchenko,N. V.; Bolestova, G. I.; Zeifman, Y. V.; Fialkov, Y. A.; Parnes, N. A. Mendeleev Commun. 1991, 1, 118. (b) Terao, J.; Begum, S. A.; Shinohara, Y.; Tomita, M.; Naitoh, Y.; Kambe, N. Chem. Commun. 2007, 855. (c) Klahn, M.; Fischer, C.; Spannenberg, A.; Rosenthal, U.; Krossing, I. Tetrahedron Lett. 2007, 48, 8900. (d) Gu, W.; Haneline, M. R.; Douvris, C.; Ozerov, O. V. J. Am. Chem. Soc. 2009, $131,11203$.

(9) (a) Hounjet, L. J.; Caputo, C. B.; Stephan, D. W. Dalton Trans., 2013, 42, 2629. (b) Caputo, C. B.; Hounjet, L. J.; Dobrovetsky, R.; Stephan, D.W. Science 2013, 341, 1374. (c) Holthausen, M. H.; Mehta, M.; Stephan, D. W.; Angew. Chem. Int. Ed. 2014, 126, 6538.

(10) (a) Tay M. Q. Y., Lu Y., Ganguly R., Vidović D. Angew. Chem. Int. Ed. 2013, 52, 3132. (b) Tay M. Q. Y., Lu Y., Ganguly R., Vidović D. Chem. Eur. J. 2014, 20, 6628.

(11) The name was introduced by Frenking: (a) Toner, R.; Öxler, F.; Neumüller, B.; Petz, W.; Frenking, G. Angew. Chem. Int. Ed. 2006, 45, 8038. (b) Tonner, R.; Frenking, G. Angew. Chem. Int. Ed. 2007, 46, 8695. (c) Deshmukh, M. M.; Gadre, S. R.; Tonner, R.; Frenking, G. Phys. Chem. Chem. Phys. 2008, 10, 2298. (d) Tonner, R.; Frenking, G. Chem. Eur. J. 2008, 14, 3260. (e) Takagi, N.; Shimizu, T.; Frenking, G. Chem. Eur. J. 2009, 15, 8593. (f) Frenking, G.; Tonner, R. Pure Appl. Chem. 2009, 81, 597. (g) Takagi, N.; Shimizu, T.; Frenking, G. Chem. Eur. J. 2009, 15, 3448. (h) Tonner, R.; Frenking, G. Chem. Eur. J. 2008, 14, 3273.

(12) Burford, N.; Ragogna, P. J.; McDonald, R.; Ferguson; M. J.; J. Am. Chem. Soc. 2003, 125, 14404.

(13) For $\left[\mathrm{BAr}_{4}^{\mathrm{f}}\right]^{-}$decomposition reports, see: (a) Bahr, S. R.; Boudjouk, P. J. Am. Chem. Soc. 1993, 115, 4514.; (b) Ferraris, D.; Cox, C.; Anand, R.; Lectka, T. J. Am. Chem. Soc. 1997, 119, 4319.

(14) El-Nahas, A. M.; Clark, T. J. Org. Chem. 1995, 60, 8023-8027.

(15) It is worth mentioning that orbitals found on the $\mathrm{Ph}$ rings of the carbone ligand are also involved in the formation of the HOMO.

(16) Ellis, B. D.; Ragogna, P. J.; Macdonald, C. L. B. Inorg. Chem. 2004, 43, 7857 . 
For Table of Contents Only

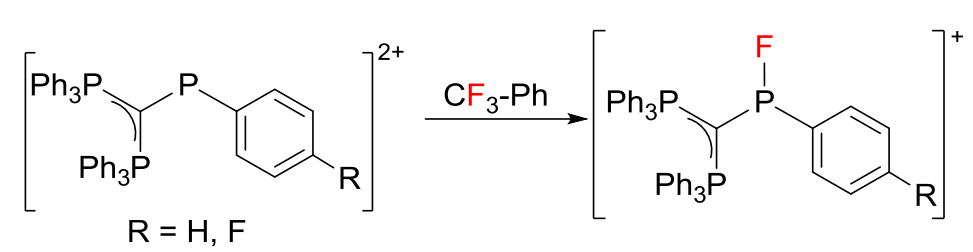

Heterolytic cleavage of C-F bonds by a couple of transient phosphenium dications is reported. One of the highly reactive species was trapped by a Lewis base. Computational analysis suggested that the lowlying LUMOs of these dications were mainly responsible for the observed activity. 